\title{
Ben Sorun Çözebilirim (BSÇ) Programının Etkililiği: Okul Öncesi Dönemi Çocukları Üzerinde Deneysel Bir Araştırma
}

Hilal Zorlu, Ankara Üniversitesi. ORCID ID: 0000-0002-5840-1689

Selahiddin Öğülmüş, Ankara Üniversitesi. ORCID ID: 0000-0002-8737-5141

Öz

Bu araştırmanın amacı, Myrna Shure (1992) tarafından geliştirilen Ben Sorun Çözebilirim (BSÇ) Programının 4-5 yaşlarındaki çocuklar üzerindeki etkililiğini incelemektir. Bu program çocukların düşünme becerilerini geliştirmeye yönelik olarak tasarlanmıştır. Programın en önemli özelliği, çocuklara sorun çözmeye ilişkin karar verme sürecinde ne yapacaklarını ya da düşüneceklerini değil, nasıl düşüneceklerini ögretmesidir. BSÇ 25 yılı aşkın çalışmaların sonucunda elde edilmiş kapsamlı ve uygulanması uluslararası düzeyde desteklenen bir programdır. Araştırma modeli, ön test - son test deney kontrol gruplu desene dayalı bir araştırmadır. Deney ve kontrol grubu, Balıkesir'de bir devlet anaokuluna devam eden 34 çocuktan oluşmaktadır. Deney grubunda yer alan çocuklara araştırmacı tarafından 5 ay süreyle 59 dersten oluşan Kişiler Arası Sorun Çözme Becerileri Eğitimi Programının okul öncesi çocuklar için geliştirilen formunun Türkçesi uygulanmış ve "Okul Öncesi Çocuklar Iç̧in Kişiler Arası Sorun Çözme Testi" veri toplama aracı olarak kullanılmıştır. Deney ve kontrol gruplarında yer alan çocukların ön test puanlarının arasındaki farkın anlamlılı̆ını test etmek için bağımsız örneklemler $t$ testi yapılmıştır. Deney ve kontrol gruplarının ön test son test puan ortalamalarının anlamlılı̆ını test etmek için Karışık Desenler için Varyans Analizi tekniği uygulanmıştır. Araştırmada BSÇ eğitimi alan çocukların kişiler arası sorun çözme beceri puanlarının kontrol grubuna oranla anlamlı bir şekilde yüksek olduğu sonucuna ulaşılmıştır. Bu bulgu BSÇ programının çocukların kişiler arası sorun çözme becerileri üzerinde etkili olduğunu göstermektedir.

Anahtar Kelimeler: kişiler arası sorun çözme, düşünme eğitimi, ben sorun çözebilirim programı

İnönü Üniversitesi

Eğitim Fakültesi Dergisi

Cilt 21, Sayı 1, 2020

ss. $270-283$

DOI: $10.17679 /$ inuefd. 521367

Makale türü:

Araştırma makalesi

\section{Önerilen Atıf}

Zorlu, H., Öğülmüş, S. (2020). Ben Sorun Çözebilirim (BSÇ) Programının Etkililiği: Okul Öncesi Dönemi Çocukları Üzerinde Deneysel Bir Araştırma. Inönü Üniversitesi Eğitim Fakültesi Dergisi, 21(1), 270-283. DOI: 10.17679/inuefd.521367 


\section{TÜRKÇE GENIŞLETiLMIŞ ÖZET}

\section{Giriş}

Okul öncesi eğitim çocukların bilişsel, duyuşsal ve davranışsal gelişimleri için uygun sosyalleşme ortamı sağlayarak hem akranları hem de yetişkinlerle ilişkilerinin sağlıkı bir şekilde yürütülmesinde kolaylaştıııı bir rol oynamaktadır. Alanyazında kişiler arası sorun çözmenin, bu eğitimin önemli bir yönünü ifade eden öğrenilebilen bir beceri olduğu ve uygun yapılandırılmış eğitim programları ile bu kazanımların sağlanabileceği belirtilmektedir. Çocuklarda kişiler arası sorun çözme becerilerini geliştirmeye dönük sistematik eğitim modellerinden birisi "Bilişsel Yaklaşıma Dayalı Kişiler Arası Sorun Çözme" (Interpersonal Cognitive Problem Solving / ICPS) diğer bir adıyla Ben Sorun Çözebilirim (BSÇ) Programıdır. Bu program temel olarak çocuklarda farklı düşünme becerilerine odaklanmaktadır. Yaklaşımın en önemli özelliği, çocuklara sorun çözmeye ilişkin karar verme sürecinde ne yapacaklarını ya da düşüneceklerini değil nasıl düşüneceklerini öğretmesidir. Buna göre, düşünen bir çocuğa insanların nasıl hissettiği veya ne yaptığı anlatılmaz, düşünen çocuk insanların nasıl hissettiğini değerlendirebilir, ne yaptığına karar verebilir ve bir fikrin iyi bir fikir olup olmadığını belirleyebilir. BSÇ, çocuğun becerilerinin merkeze alındığı bir yaklaşımdır. Alanyazında erken yaşta kazandırılan sorun çözme becerilerinin çocukların pek çok açıdan gelişimine katkı sağladığı ve çocuklar için yapılandırılmış eğitimlerin yaygınlaştıııması gerektiği belirtilmektedir. Bu araştırmada BSÇ eğitiminin farklı örneklem gruplarında uygulanabilir olup olmadığı ve çocukların kişiler arası sorun çözme becerilerine etkisi araştırılmaya değer görülmüştür.

\section{Amaç}

Bu araştırmanın amacı BSÇ programının 4-5 yaş grubu okul öncesi eğitim alan çocuklar üzerindeki etkililiğini sınamaktır. BSÇ programının okul öncesi, ilkokul ve ortaokul öğrencilerine yönelik olmak üzere üç farklı versiyonu bulunmaktadır. Bu araştırmada, deney grubuna programın okul öncesi çocuklar için geliştirilen formunun Türkçesi uygulanmıştır. Programın sonunda, okul öncesi eğitim alan 4-5 yaş grubu çocuklarının kişiler arası sorun çözme becerilerinin gelişimine katkı sağlayacağı düşünülmektedir.

\section{Yöntem}

Bu araştırma deneysel yöntemlerden gerçek deneme modelleri, ön test-son test deney kontrol gruplu desene dayalı bir araştırmadır. Deney ve kontrol grubu, Balıkesir'de bir devlet anaokuluna devam eden 34 çocuktan oluşmaktadır. Araştırmada deney ve kontrol grupları deneysel koşula yansız atama yoluyla belirlenmiş̧tir. Anaokulunun iki farklı sınıfından biri deney grubu, diğeri kontrol grubu olarak rastgele belirlenmiştir. Araştırma grubundaki çocuklar, deney grubu $(n=17)$ ve kontrol grubu $(n=17)$ olmak üzere, bulundukları sınıfa göre iki gruptan birinde yer almışlardır. Deney grubunda 8 kız, 9 erkek, kontrol grubunda ise $7 \mathrm{kız}, 10$ erkek çocuk bulunmaktadır. Deney grubunda yer alan çocuklara araştırmacı tarafından 5 ay süreyle 59 dersten oluşan Kişiler Arası Sorun Çözme Becerileri Eğitim Programı uygulanmışıır. Bu araştırmada "Okul Öncesi Çocuklar İçin Kişiler Arası Sorun Çözme Testi" veri toplama aracı olarak kullanılmışıı. Bu test, okul öncesi çocukların gündelik yaşamdaki kişiler arası sorunları çözmedeki bilişsel becerilerini ölçmektedir. Kişiler Arası Sorun Çözme Becerileri Testi, iki çocuk arasında veya anne baba ile çocuk arasında ortaya çıkabilecek sorunları içeren öykülerden oluşmaktadır. Test kullanımı için gerekli eğitim, materyal ve izinler araştırma öncesinde alınmıştır. Test her bir çocuğa bireysel olarak uygulanmıştır. Araştırmadan elde edilen veriler SPSS 22.0 paket programıyla analiz edilmiştir. Deney ve kontrol gruplarında yer alan çocukların Kişiler Arası Sorun Çözme Testi ön test puanlarının arasındaki farkın anlamlıı̆ı̆ını test etmek için bağımsız örneklemler $t$ testi yapılmıştır. Deney ve kontrol gruplarının ön test ve son test toplam çözüm puan ortalamaları arasındaki farkın anlamlıı̆ııı test etmek için Karışık Desenler için Varyans Analizi tekniği uygulanmıştır.

\section{Bulgular}

Araşıłırmada deney ve kontrol gruplarında yer alan çocukların Kişiler Arası Sorun Çözme Testi ön test puanlarının arasındaki farkın anlamlıı̆ı̆ını test etmek için yapılan bağımsız örneklemler $\mathrm{t}$ testinde $\mathrm{t}_{(32)}=0.325$ ( $p>$.05) sonucu elde edilmiştir. Bu bulgu işlem öncesinde gruplar arasında anlamlı bir fark olmadığını; diğer bir deyişle deney ve kontrol gruplarının benzer özelliklere sahip olduğunu göstermektedir. Araştırmada ikinci olarak deney ve kontrol gruplarının ön test ve son test toplam çözüm puan ortalamaları arasındaki farkın anlamlıı̆ını test etmek için Karışık Desenler için Varyans Analizi tekniği uygulanmıştır. Analiz 
sonucunda elde edilen $[F(1,34)=95.095, p<.05]$ değeri grupların ön test son test toplam çözüm puanları arasındaki farkın anlamlı olduğunu ifade etmektedir. Bu bulgu kişilerarası sorun çözme beceri eğitiminin deney grubu çocukları üzerinde etkili olduğunu göstermektedir.

\section{Tartışma, Sonuç ve Öneriler}

Araştırma sonucunda elde edilen bulgular, kişiler arası sorun çözme becerileri eğitiminin, alanyazındaki araştırma bulguları ile benzer şekilde çocukların sorun çözme becerileri üzerinde etkili olduğunu göstermektedir. Farklı örneklem gruplarında uygulandığında tutarlı sonuçlar elde edilmesi programın genellenebilir özelliğe sahip olduğunu göstermektedir. Ülkemizde bu şekilde yapılandırılmış eğitimlere okul öncesi çocukların ihtiyaç duyduğu ve yaygınlaştırılması gerektiği düşünülmektedir.

Araştırmalar, BSÇ programının sadece çocukların kişiler arası soru çözme becerilerini arttırmakla kalmayıp aynı zamanda akademik başarıları, öz düzenleme becerileri ve perspektif alma becerilerini artırmak gibi pek çok olumlu etkiye sahip olduğunu göstermektedir. Gelecek araştırmalarda eğitimin çocukların empati, öz güven ve atılganlık becerilerine olan etkisinin incelenmesi önerilebilir.

$\mathrm{Bu}$ araştırmada deney grubunda yer alan çocukların aileleri işlem öncesinde programa ilişkin olarak bilgilendirilmiştir. Eğitim sonrasında ise bireysel olarak değerlendirme yapılmış ve ailelerden geribildirimler alınmış olmasına karşın eğitimin etkililiğinin artırılması için ailelerin sürece daha aktif bir şekilde dahil edilmesi gerektiği düşünülmektedir. Nitekim BSÇ'nin etkili bir şekilde uygulanması evde de karşılaşılan sorunlara benzer yaklaşım sergilenmesini gerektirmektedir.

Alanyazında eğitimin kalıcılığını test edebilmek için yapılan izleme çalışmalarında, eğitimin süreklilik içermesi gerektiği bildirilmektedir. Eğitimin sürekli ve yaşa uygun olarak planlanmış programlarla sürdürülmesi, eğitimin kalıcılığını ve bir yaşam becerisi olarak bireyde yerleşmesini sağlayacaktır. Ancak bunun için çocuğun sıklıkla ilişkide bulunduğu öğretmenlerin de bilişsel yaklaşıma dayalı sorun çözme eğitiminden geçmesi gerektiği düşünülmektedir.

Bu eğitim çocukların kelime dağarcıklarını geliştirerek kavramları öğrenme, kendi duygularını ve başkalarının duygularını anlamayı ve kontrol etmeyi sağlama, bir sorunun birden fazla çözüm yolu olduğunu, farklı yolların farklı sonuçlar doğurabileceğini öğrenme ve ihtimalleri göz önünde bulundurmayı içeren bir "düşünme eğitimi"dir. Uygulaması uzun zaman almasına karşın süreç eğlenceli bir şekilde yürütülmüştür. Program sonunda deney grubundaki çocuklara sertifika töreni yapılmış, program boyunca öğrenilen konuları içeren oyun ve şarkılar içeren bir gösteri düzenlenmiş ve çocuklara BSÇ sertifikaları verilmiştir. Bu uygulamanın, çocukların "BSÇ Çocuğu" olma motivasyonunu ve sorumluluğunu arttırdığı düşünülmektedir. 


\title{
The Effectiveness of I Can Problem Solve (ICPS) Program: An Empirical Research on Preschoolers
}

\author{
Hilal Zorlu, Ankara University, ORCID ID: 0000-0002-5840-1689 \\ Selahiddin Öğülmüşs, Ankara University, ORCID ID: 0000-0002-8737-5141
}

\begin{abstract}
The aim of this study is to examine the effectiveness of I Can Problem Solve / ICPS Program developed by Shure (1992) of those children attending preschool education programs in the age of 4-5. This program is designed to develop children's thinking skills. The most important feature of the program is that it teaches children how to think, not what to do or think in the decision-making process for problem-solving. ICPS is a comprehensive and internationally supported program that was developed as a result of more than 25 years of studies. This research is based on real experimental models from experimental methods, pretest-posttest control group design. Experimental and control groups were composed of 34 children who attend a state preschool in Balikesir. The researcher administered 59 sessions Interpersonal Problem-Solving Skills Education Program, adopted into Turkish form for preschool children to the experimental group for five months. Preschool Interpersonal ProblemSolving Test was used for data collection tool in the study. Independent samples t-test was used to compare the pretest of the groups. Split Plot ANOVA was used for comparing of the groups pretest and posttest scores. The findings showed that ICPS given to children was effective in developing their interpersonal problem solving skills.
\end{abstract}

Keywords: problem solving, thinking training, i can problem solve program

\section{İnönü University}

Journal of the Faculty of Education Vol 21, No 1, 2020

pp. 270-283

DOI: $10.17679 /$ inuefd. 521367

Article type:

Research article
Received :02.02.2019

Accepted : 18.02.2020

\section{Suggested Citation}

Zorlu, H. \& Öğülmüş, S. (2020). The Effectiveness of I Can Problem Solve (ICPS) Program: An Empirical Research on Preschoolers, Inonu University Journal of the Faculty of Education, 21(1), 270-283. DOI: 10.17679/inuefd.521367 


\section{INTRODUCTION}

Preschool education plays a facilitative role in providing an appropriate socialization environment for children's cognitive, affective and behavioral development and managing healthy relationships with both their peers and adults. Supporting the development of children who mostly completed their mental development between the ages of 0 to 6 with appropriate educational activities is incredibly important in terms of regulating their social and academic skills in the years to come (Fan \& Chen, 2001, p. 20). Kağıtçıbaşı, Sunar, Berkmen, and Cemalcılar (2004) proved the effect of pre-school education on children's mental development and academic success with a scientific research embracing 22 years.

It is inevitable that the children who live in interaction with their peers in preschool period experience satisfactory events as well as facing problems. According to Piaget (1983), interpersonal problems contribute to the development of children in terms of understanding others' thoughts and moving away from egocentrism (Dereli İman, 2014). However, children often solve their problems with ineffective methods. Some cry and shout; some hit or bite; and some do not tell the truth to their parents or teachers. These methods create new problems rather than provide satisfactory solutions to children's problems (Yılmaz, 2019). Özdil (2008) stated that most of the students do not have sufficient equipment to constructively manage their interpersonal problems. Therefore, it is thought that children need to gain effective problem-solving skills.

Solving problems is defined as a cognitive and behavioral process by the author in which the difference between the existent situation and the intended goal is perceived and the tension that stem from this situation is defused (2006). Problem-solving is a learnable skill (Yıldırım, Hacıhasanoğlu, Karakurt, \& Türkleş, 2011) and there are many benefits if children gain this skill at an early age. It is important to gain this skill at an early age because it helps children to increase their academic success, establish positive interpersonal relationships with friends and adults, improve healthy developmental functions, and prevent more serious problems from happening (Reid, 2003, as cited in Kargı, 2009, p.38). Similarly, problemsolving promotes that children consider other people's views, develop an understanding of social relations, and take responsibility for their behaviors with their peers (Dalkılıç, 2014; Gök, 2009; Terzi, 2003). Bingham (2004) stated that children with an ability to solve problems know how to take advantage of the opportunities they encounter, find different solutions to overcome the difficulties they face, wonder everything, ask questions, and make predictions. In a nutshell, the ability to solve interpersonal problems is a skill which must be supported during preschool period and its effects last lifelong (Akbaş, 2005; Aksüt, 2015; Anlıak \& Dinçer, 2005; Bal, 2018; Emir, 2016; Kaçar, 2016; Karayol, 2016; Mercan, 2019; Oğuz, 2012). In literature, there are scientific proofs that show children can acquire this skill from the age of 4 (Shure, 2001; Ünal \& Aral, 2014).

A great deal of studies have been conducted about interpersonal problem-solving skills during preschool period in our country and abroad (Alemdar Coşkun, 2016; Anlıak \& Dinçer, 2005; Anlıak \& Şahin, 2010; Aras, 2018; Bal, 2013; Dalkılıç, 2014; Dilber, 2015; Dinçer \& Guneysu, 1997, 2001; Domitrovich, Cortes, \& Greenberg, 2007; Emir, 2016; Işıktekiner, 2014; Kaan, 2013; Kargı, 2009; Kaytez \& Kadan, 2016; Keçecioğlu, 2015; Kesicioğlu, 2015; Koruklu \& Yılmaz, 2010; Mercan, 2019; Mermer, 2017; Öğülmüş \& Kargı, 2015; Özdil, 2008; Shure 1992a; Tangül Özcan, 2007; Türköz, 2007; Yoleri, 2014). When some of these studies are examined, it is seen that some of them involve the implementation of educational programs aimed at developing interpersonal problem solving skills of children (Alemdar Coşkun, 2016; Anlıak, 2004; Anlıak \& Şahin, 2010; Aras, 2018; Dinçer \& Güneysu, 1997; Işıktekiner, 2014; Kaan, 2013; Kargı, 2009; Koruklu \& Yılmaz, 2010; Mermer, 2017; Özdil, 2008; Tangül Özcan, 2007). In some other studies, it is seen that the relationship between children's interpersonal problem solving skills and academic self-esteem (Kaytez \& Kadan, 2016), watching television and family structure (Kesicioğlu, 2015), attachment styles (Türköz, 2007), social emotional adjustment (Dalkılıç, 2014), self-regulation skills (Mercan, 2019), perceptions of marital conflict (Emir, 2016), moral judgment (Dilber, 2015), and perspective taking skills (Aras, 2018; Bal, 2013) is examined.

Interpersonal problem-solving skill enables to solve interpersonal problems quickly and efficiently with the developed systematic models and the teaching of these models. If taught particularly at schools and in family, these aforementioned models help children, teenagers, and adults to solve interpersonal problems (Kenç, 2004). Haim Ginott's work called "Between Parent and Child" that was written in 1965 is the first sample of these models. Thomas Gordon's work called "Parent-Teacher Effectiveness Training", Phillip Mountrose's "5 Steps Model for Problem-Solving with Children Ages 6 to 18" (Swets, 1998), Littlefield's "The Problem-Solving Model" based on cognitive approach (Davidson \& Wood, 2004) and in our country Kenç's (2004) "8 Steps for Effective Problem-Solving Model" are other models created to develop interpersonal problem-solving skills. In addition, there are models designed directly for preschool children. 
The Second Step Violence Prevention Curriculum (Committee for Children, 1997), Preschool PATHS (Promoting Alternative Thinking Strategies; Domitrovich et al., 2007), Incredible Years Dinosaur Social Skills and Problem-Solving Curriculum (Webster-Stratton \& Reid, 2003), and I Can Problem Solve Program (Shure, 1992a) are designed to directly develop interpersonal problem-solving skills of preschool children. The Second Step Violence Prevention Program was developed to support children's social and emotional skills. The Second Step program teaches children to think about the emotions of other children, to solve problems in cooperation, and to deal with anger in a positive way. The program includes empathy, impulse control and anger management skills (Committee for Children, 1997). Incredible Years Dinosaur Social Skills and Problem-Solving Program was developed to address problems such as behavioral problems, attention problems, and peer rejection of children (Webster Stratton \& Reid, 2003). It was found that adaptation and application of Incredible Years Intervention Program Child Training, which was developed for children in early childhood, were effective for Turkish culture (Coşkun, 2008; Dereli, 2008; Uysal, 2016). Preschool PATHS program, which is integrated into standard education programs, aims to develop emotional awareness and communication, self-control, self-perception, peer relationships, and social problem-solving skills (Domitrovich et al., 2007). The program includes activities such as story books, puppets, and emotion cards (Hamre, Pianta, Mashburn, \& Downer, 2012).

Interpersonal Cognitive Problem-Solving (ICPS) developed by Shure (1992a) or so-called I Can Solve Problem (ICPS) program is designed to develop children's thinking skills. The most important feature of the program is that it teaches children how to think, not what to do or think in the decision-making process for interpersonal problem-solving. This program is one of the most comprehensive research programs on teaching of interpersonal problem-solving skills (Anlıak, 2004; Kargı, 2009; Öğülmüş \& Kargı, 2015; Shure, 2001). It was started to be generated by Spivak and Shure in the early 1970 s and it was obtained after clinic studies that lasted more than twenty-five years (Shure, 1992a). This research is based on ICPS.

ICPS program is composed of two main parts: In the first part there are lessons in which the pre-skills are thought to children to solve problems and in the second part the lessons in which the skills to solve problems are taught. The first part of the program, The Pre-Skills to Solve Problems, includes learning the necessary vocabulary, knowing his/her and others' emotions, and caring about others' perspective. The vocabulary taught in the first part of the program is important and preparatory in the later process of improving problem-solving thinking practice. Other lessons help children to learn about both their feelings and others' feelings, there are more than one way to understand what another person feels and to perceive that different people can feel different things vis-à-vis the same situation. ICPS concepts and lessons teach children not only to understand others' feelings but also the ways to influence them. On the other hand, the second part of the program, Problem-Solving Skills includes thinking about more than one solution, caring about the possible results of each solution, and deciding which solution will be chosen (Shure, 1992a).

ICPS is an approach that puts the skills of children into center. Children experience stress and anger in line with the problems they live with their peers and adults. In order to eliminate the irritation they feel at the time, they apply the first method that comes to their mind first and they do not think the causes of their behavior. In problem-solving training, the familiarization with the ICPS concepts help children to think about many possible solutions instead of applying the first idea that comes to their mind. The positive expression of negative feelings can also affect the relationships positively (Ladd Kochenderfer, Ladd, \& Coleman, 1996). For example, the concepts of some/all are an important factor in order to differentiate the problematic situation from the unproblematic one. Similarly, the concepts of same/different are problemsolving words that help children to think "different people can feel different ways about the same thing". The concepts included in ICPS training greatly influence the vocabulary of children and their approach to problems. The studies conducted show that the skills in understanding children's emotions influence their interpersonal problem-solving skills positively (Dereli, 2008; Yılmaz, 2012). There are three different versions of ICPS program as preschool, primary school and secondary school. In this research, the preschool version of the program consisting of 59 lessons for preschool children was employed. This program is applied to children with a play-based approach in which games, stories, pictures, puppets, and drama techniques were used. Therefore, children have fun while learning. The primary benefits of the program can be listed as creating self-confidence in children, encouraging children to think about alternative solutions, enabling new ways to deal with problems, increasing social interaction with their peers, improving their awareness and sensitiveness about others, and increasing independency of children. On the other hand, the benefits of ICPS program for teachers can be listed as consolidating other objectives in the school curriculum, creating a more positive class atmosphere, decreasing the time spared in disagreements, giving a learning opportunity to have lessons that are overlapping like a pyramid, making children gain new skills that can also be applicable in real life situations, and increasing the 
problem-solving skills of teachers (Kargı, 2009, p.64). ICPS is a thinking education and according to Einstein, "the purpose of education is not to teach the truth, but to teach thinking". Human beings are able to produce solutions to problems through their thinking power. Thinking is the work of making connections between concepts and propositions (Duman, 2009, p.353). Children who do not yet have the thinking ability of adults need to develop their thinking and problem-solving skills (Altan, 2018). In a series of studies in which ICPS program are implemented in Turkey, the effectiveness of the program in Turkish culture was determined (Anlıak, 2004; Anlıak \& Şahin, 2010; Aras, 2018; Kaan, 2013; Kargı, 2009; Tangül Özcan, 2007). But when the literature is examined, it is often emphasized that preventive intervention programs developed for preschool children support social-emotional and academic skills, develop interpersonal problem-solving and thinking skills and increase positive behaviors. It is stated that preventive intervention programs should not be limited to the applied regions but should be expanded rapidly (Anlıak, 2004; Ocak \& Arda, 2011). Therefore, it is worth investigating the ICPS in different sample groups and disseminating the program.

The purpose of this research is to test the effectiveness of the ICPS program on preschool children who are in the age of 4-5. In this research, the Turkish form of ICPS program developed by the author for preschool children was conducted to the experiment group (2006). It is thought that the program contributes to interpersonal problem-solving skills of the preschool children in the age of 4-5.

\section{METHOD}

\section{Research Design}

This research is based on real experimental models from experimental methods, pretest-posttest control group design.

\section{Research Sample}

Experimental and control groups were composed of 34 children who attend a state preschool in Balıkesir, Turkey. In the research, of the two preschool classes, one was stated as experimental group and the other one was stated as control group randomly. Experimental and control groups were independent of each other in order to continue teaching and learning process with separate class and separate teachers. The children in the research were placed in one of the groups as experimental $(n=17)$ or control group $(n=17)$ according to their classes they attend. There were $8 \mathrm{girls}$ and 9 boys in the experimental group and there were 7 girls and 10 boys in the control group. Pretests were given to children who were in experimental and control group in October and November of 2017. Before the pretests, an informative meeting was held for the parents of the children to summarize the aim, method and content of ICPS program and research and their permission was received to do these prosecutions. Subsequent to completing the pretests, ICPS program made up of 59 lessons were applied to children in experimental group for 5 months between December 2017 and May 2018 by the researcher. The training with experimental group was applied twice a week on average and each lesson lasted about 30 minutes. On the other hand, in the control group the researcher attended the curriculum activities of the class teacher as a guest teacher and the children were observed during the process.

\section{Research Instrument and Procedure}

In this research, Preschool Interpersonal Problem-Solving Test (PIPS) that was developed by Spivack and Shure in 1990 and adapted to our language by Dinçer as OKPÇ (1995) was used as a data collection tool. This test measures the cognitive skills of preschool children in solving interpersonal problems in daily life. The validity and reliability of PIPS was tested in various researches by Shure and her friends (Shure, 1992b). It was expressed that the scale was able to separate the children who behave differently in terms of behavioral adaptation and the changes at the end of the training in the studies concerning the construct validity of the scale. Test-retest method was used by Shure (1992b) in the original reliability study of PIPS and the reliability index of the test was stated as $r=0.72$. In another study done by Anlıak and Dinçer (2005), the reliability index of test-retest was found 0.85 . Furthermore, it was found that the agreement percentage within peer and mother parts varied between $\% 82$ and \%99 between coders. Similar results were obtained in validity and reliability studies conducted by Anlıak (2004). It was seen that the scale was used in many studies investigating interpersonal problem-solving skills on children (Anlıak, 2004; Bal, 2013; Dalkılıç, 2014; Işıktekiner, 2014; Kargı, 2009; Özdil, 2008).

Pretest and posttest were applied to each child individually. The materials which were necessary to conduct the test were 13 toy pictures (a truck, a doll, a kite, a shovel, a hammock, a boat, a whirligig, a drum, a teddy bear, a piano, a guitar, a phone, a weeble) and mother, daughter and son pictures. The scores got from the PIPS test reflect the total number of different solutions which were suggested to peer problems and mother-child problems. There are scoring papers to which the answers of the children will be 
transferred according to the coding criteria in order to score the test. Training to conduct PIPS test, test materials, and the permission of conduct was taken from Professor Çağlayan Dinçer, an academic at Ankara University in Pre-School Education Department.

\section{Data Analysis}

The data obtained from the research was analyzed with SPSS 22.0 package program. Independent sample $t$ test was used in order to test the meaningfulness of the Interpersonal Problem-Solving pretest score difference among the children who were in experimental and control groups. Split plot ANOVA was employed to compare the experimental and control group pretest scores and posttest scores. Before deciding the analysis technique, the data was examined whether it is appropriate for parametric tests usage. For the validity and inter-relaibility of analysis of split plot ANOVA, it is vital that the assumptions such as groups are independent of each other, group variance is equal, dependent variable is spaced or proportional and the distribution is normal must be fulfilled (Kalaycl, 2014). Accordingly, $p$ value in Shapiro-Wilk test was bigger than 0.05 (pretest $=0.06$, posttest=0.08), the distribution was normal and the equality of group variance in Levene's test (Sig. Value. 0.47 ) and it was decided that it was appropriate for both $t$ test and ANOVA for repeated measures test by corresponding measurements.

\section{FINDINGS}

In this research, the hypothesis suggesting that there is a difference between the interpersonal problemsolving points - total solution score- of the children who had Interpersonal Problem-Solving Skills Training in the experimental group and interpersonal problem-solving scores-total solution score-of the children who did not have this training has been tested. For this process, the solution that each child in the experimental and control group offered to problematic situations (mother-child and peer problem stories) and the total solution numbers have been measured as the pretest. The same measurements have been repeated as the posttest at the end of the program. Total solution scores of the subjects in the experimental and control group acquired by this method are shown in Table 1.

Table 1

The Numeric Division of Solution Suggestions That Children in Experimental and Control Groups Produced Under Problematic Situations

\begin{tabular}{lllll}
\hline Subject Number & \multicolumn{2}{c}{ Experimental Group } & \multicolumn{2}{c}{ Control Group } \\
1 & Pretest & Posttest & Pretest & Posttest \\
2 & 7 & 14 & 5 & 7 \\
3 & 7 & 12 & 7 & 10 \\
4 & 6 & 13 & 8 & 11 \\
5 & 5 & 10 & 6 & 8 \\
6 & 6 & 13 & 4 & 8 \\
7 & 8 & 16 & 6 & 7 \\
8 & 8 & 15 & 4 & 6 \\
9 & 3 & 11 & 5 & 10 \\
10 & 5 & 13 & 8 & 10 \\
11 & 8 & 15 & 4 & 6 \\
12 & 5 & 10 & 7 & 9 \\
13 & 4 & 9 & 8 & 7 \\
14 & 3 & 8 & 5 & 9 \\
15 & 4 & 9 & 7 & 8 \\
16 & 13 & 5 & 8 \\
17 & 5 & 11 & 7 & 8 \\
\hline Total & 5 & 6 & 142 \\
$\overline{\boldsymbol{x}}$ & 4 & 201 & 102 & 8.35 \\
Ss & 5 & 11.82 & 1.41 & 1.55 \\
\hline
\end{tabular}

It was discovered that the average score of pretest belonging to experimental group was $\overline{\boldsymbol{x}}=5.47$ and the average score of pretest belonging to control group was $\overline{\boldsymbol{x}}=6$. An independent samples $t$ test was conducted in order to test the meaningfulness of the difference between the average Interpersonal Problem-Solving pretest scores of the children in the experimental and control groups. According to the independent samples $t$ test result, the difference between the groups was not found meaningful $t_{(32)}=$ 
0.325 ( $p>$.05). This finding shows that problem-solving skills of the experimental and control groups before the training does have similar characteristics.

In Table 1, according to the posttest scores of the groups; total scores of the experimental group increased to 201 from 93 and control group's total scores increased to 142 from 102 . Similarly, the arithmetic means in experimental group increased from 5.47 to 11.82; the arithmetic means in control groups increased from 6 to 8.35. It was seen that the children in the experimental group doubled their solution suggestions on average. The increase in the control group was less than the experimental group. This increase in the control group can be explained by other educational activities in the preschool curriculum. The researchers state that preschool education programs for healthy human relations should be prepared based on activities that will provide interpersonal problem-solving skills (Anlıak \& Dinçer, 2005; Mermer, 2017). In Turkey, achievements and indicators for children's problem-solving skills were included in the field regarding the cognitive development of Preschool Education Program of the Ministry of Education, which was updated in 2013 (MEB, 2013). However, the pretest and posttest results of the experimental and control groups showed that ICPS was more effective than the current program.

In order to test the meaningfulness of the increase, split plot ANOVA was used with the experimental and control group pretest and posttest scores. The results of the analysis are given in Table 2.

Table 2

ANOVA Results According to the Experimental and Control Group Pretest and Posttest Scores

\begin{tabular}{|c|c|c|c|c|c|}
\hline $\begin{array}{l}\text { The Source of the } \\
\text { Variance }\end{array}$ & $\begin{array}{l}\text { Sum } \\
\text { Squares }\end{array}$ & of $s d$ & Mean Square & $\mathrm{F}$ & $p$ \\
\hline Groups & 36.765 & 1 & 36.765 & 741.45 & .017 \\
\hline Measure & 322.118 & 1 & 322.118 & & \\
\hline Groups*measure & 68 & 1 & 68 & 95.095 & .000 \\
\hline Error & 183.706 & 32 & 5.741 & & \\
\hline Total & 610.589 & 34 & & & \\
\hline
\end{tabular}

According to split plot ANOVA results, a meaningful difference was found between the pretest score averages and posttest score averages in relation to interpersonal problem-solving test of experimental and control groups participated in the research $[\mathrm{F}(1,34)=95.095, p<.05]$. Namely, the research finding stating that the problem-solving skills scores of children who had the training regarding interpersonal problemsolving skills were meaningfully higher than the control group. This finding points to the applicability and effectiveness of the ICPS program in Turkish culture as in previous studies (Anlıak, 2004; Anlıak \& Şahin, 2010; Aras, 2018; Kaan, 2013; Kargı, 2009; Tangül Özcan, 2007). In this study, although the effect of the program on a different variable was not investigated, it was seen that children acquired many social skills along with the development of problem-solving skills (Dereli İman, 2014; Hune \& Nelson, 2002; Özmen, 2013).

\section{DISCUSSION \& CONCLUSION}

In this research, the efficiency of interpersonal problem-solving training based on cognitive approach, which was given to children aged 4-5 years who were educated at a state school, was investigated. The results of the research showed that interpersonal problem-solving training is effective on the skills of problem-solving coherently along with the research findings of the literature (Anlıak, 2004; Anlıak \& Şahin, 2010; Aras, 2018; Erwin, Purves, \& Johannes, 2005; Kaan, 2013; Kargı, 2009; Shure, 1992a; Shure, 1997; Tangül Özcan, 2007). It was seen that the ICPS program gives similar results when applied in different sample groups. This situation is considered as a step towards the generalizability of the model rather than repeating the previous studies. There are a limited number of institutions that introduce such kind of farreaching programs in our country (Kaan, 2013; Öğülmüş \& Kargı, 2015). As a matter of fact, it is stated that preventive intervention programs should not be limited to the applied regions but should be expanded rapidly (Anlıak, 2004; Ocak \& Arda, 2011).

The studies show that ICPS program not only increases the interpersonal problem-solving skills of children but also decreases the problematic behaviors (Kaan, 2013; Kargı, 2009; Shure \& Spivack, 1982). Furthermore, it increases children's production of alternative solutions and their thinking skills (Erwin et al., 2005), their academic success (Tangül Özcan, 2007), self-regulation skills (Mercan, 2019), concept development (Yoleri, 2014), and perspective taking skills (Aras, 2018; Bal, 2013). From this point of view, it 
can be suggested that in the further studies the effects of ICPS training on children's empathy, selfconfidence development, and their assertiveness can be investigated.

In an another study done by Özcan and Öğülmüş (2010), ICPS training has detractive effects on the problems such as lack of attention, hyperactivity/impulsivity signs, not conforming to the rules, anxiety/depression, social introversion, crime-directed behavior, somatic problems, social problems and thinking problems of children with attention deficit and hyperactivity disorder. According to this, it can be said that ICPS training may have a preventive role in problematic children who may show destructive and antisocial behaviors in the future. In the further studies, the efficiency of the program can be tested on disadvantaged children.

The participation of parents in education is a prominent factor in terms of supporting the child development. Indeed, providing the permanency and the integrity of the aimed learning practices maintain the efficiency of the education. In this study, although the parents were informed before and after the training process, it is thought that families should participate in the process actively in order to boost the efficiency of the training. Moreover, other studies showed that families were effective in improving problem-solving skills in children (Eroğlu, 2001; Spivack \& Shure, 1985). In a study conducted by Dinçer, Anlıak, Şahin, and Karaman (2009), seminars were organized for families based on the Raising A Thinking Child Workbook of the ICPS program. Thus, the continuity of the program was strengthened at home and the approach form proposed by the program was shown by the families. In addition, at the end of the training, individual feedback was obtained from the families; however, no data analysis was performed. In subsequent research, feedback can be obtained from teachers and parents through a qualitative assessment.

In the literature, it was notified that in the observation studies education must include permanency in order to test the persistency of the training (Shure \& Spivack, 1982). The sustainability of training according to age will ensure the persistency and the placement of education as a life skill (Dinçer \& Güneysu, 2001). However, it is thought that the teachers with whom the child often interacts must be trained as well. As a matter of fact, it has been observed that teachers frequently apply primitive problem-solving methods such as "Silence! Don't cry! Apologize to your friend!" in their approach to the problems experienced by children. According to Mermer (2017), teachers entering the child's life should give children the opportunity to solve their problems themselves. Teachers should not solve children's problems; they should only guide them through the solution process.

In this research a certificate ceremony was done for the children who were in the experiment group at the end of the program. In the scope of the ceremony, a sketch including the topics learned throughout the program that was prepared by both the researcher and the preschool teacher and a show including plays and songs were organized and the children were delivered ICPS certificates. This practice is thought to increase the motivation and responsibility of children to be an "ICPS Child".

\section{REFERENCES}

Akbaş S. (2005). Okul öncesi eğitime devam eden altı yaş grubu çocukların sosyal problem çözme becerilerinin incelenmesi (Yayınlanmamış yüksek lisans tezi). Hacettepe Üniversitesi Sağlık Bilimleri Enstitüsü, Ankara.

Aksüt, P. (2015). 5-6 Yaş okul öncesi çocuklarına problem çözme becerisinin kazandırılmasında etkinlik temelli fen öğretim uygulamalarının etkisinin incelenmesi (Yayınlanmamış doktora tezi). Abant İzzet Baysal Üniversitesi Eğitim Bilimleri Enstitüsü, Bolu.

Alemdar Coşkun, M. (2016). Problem çözme eğitim programının anasınıfına devam eden çocukların problem çözme becerileri ile kişiler arası problem çözme becerilerine etkisi (Yayınlanmamış yüksek lisans tezi). Gazi Üniversitesi Eğitim Bilimleri Enstitüsü, Ankara.

Altan Y. R. (2018). Okul öncesi eğitim kurumuna devam eden 48-60 aylık çocukların ve annelerinin problem çözme becerileri arasındaki ilişkinin incelenmesi (Yayınlanmamış yüksek lisans tezi). Gazi Üniversitesi Eğitim Bilimleri Enstitüsü, Ankara.

Anlıak, Ş. (2004). Farklı eğitim yaklaşımları uygulayan okul öncesi eğitim kurumlarında kişilerarası bilişsel problem çözme becerisi programının etkisinin incelenmesi (Yayınlanmamış doktora tezi). Ege Üniversitesi Sosyal Bilimler Enstitüsü, İzmir. 
Anlıak, Ş., \& Dinçer, Ç. (2005). Farklı eğitim yaklaşımları uygulayan okul öncesi eğitim kurumlarına devam eden çocukların kişiler arası problem çözme becerilerinin değerlendirilmesi. Ankara Üniversitesi Eğitim Bilimleri Fakültesi Dergisi, 38(1), 149-166. https://doi.org/10.1501/ankara-655

Anlıak, S. \& Şahin, D. (2010). An observational study for evaluating the effects of interpersonal problem solving skills training on behavioral dimensions, Early Child Development and Care, 180(8), 995 1003. https://doi.org/10.1080/03004430802670819

Aras, C. Y. (2018). Okul öncesi çocukların bakış açısı alma becerilerine "ben sorun çözebilirim programı"nın etkisi (Yayınlanmamış yüksek lisans tezi). Çukurova Üniversitesi Sosyal Bilimler Enstitüsü, Adana.

Bal, E. (2018). FeTeMM (fen, teknoloji, mühendislik, matematik) Etkinliklerinin 48-72 aylık okul öncesi çocuklarının bilimsel süreç ve problem çözme becerileri üzerindeki etkisinin incelenmesi. (Yayınlanmamış yüksek lisans tezi). Marmara Üniversitesi Eğitim Bilimleri Enstitüsü, İstanbul.

Bal, Ö. (2013). Okul öncesi eğitim kurumlarına devam eden 4- 6 yaş çocukların kişilerarası problem çözme becerileri ve bakış açısı alma becerileri arasındaki ilişkinin incelenmesi (Yayınlanmamış yüksek lisans tezi). Gazi Üniversitesi Eğitim Bilimleri Enstitüsü, Ankara.

Bingham, A. (2004). Çocuklarda problem çözme yeteneklerinin geliştirilmesi, (4th ed.). (F. Oğuzkan Çev.). İstanbul: Milli Eğitim Basımevi.

Committee for Children. (1997). Second step: A violence prevention curriculum; Middle school/junior high. Seattle, WA: Author.

Coşkun, L. (2008). An adaptation and pilot ımplementation of an effective ıntervention program targeting externalizing behaviors in early childhood (Yayımlanmamış doktora tezi). Koç Üniversitesi Sosyal Bilimler Enstitüsü Psikoloji Anabilim Dalı, İstanbul.

Dalkılıç, N. M. (2014). Okul öncesi eğitime devam eden çocukların kişiler arası problem çözme becerileri ile sosyo-duygusal uyumlarının karşılaştırılması (Yayınlanmamış yüksek Lisans Tezi). Gazi Üniversitesi Eğitim Bilimleri Enstitüsü, Ankara.

Davidson, J., \& Wood, C. (2004). A conflict resolution model. Theory Into Practice, 43(1), 6-13. https://doi.org/10.1353/tip.2004.0005.

Dereli, E. (2008). Çocuklarda sosyal problem çözme. Konya: Tablet Kitabevi.

Dereli İman, E. (2014). Değerler eğitimi programının 5-6 yaş çocukların sosyal gelişimine etkisi: sosyal beceri, psiko-sosyal gelişim ve sosyal problem çözme becerisi. Kuram ve Uygulamada Eğitim Bilimleri, 14 (1), 249-268. https://doi.org/10.12738/estp.2014.1.1679

Dinçer, Ç. (1995). Anaokuluna devam eden 5 yaş grubu çocuklarına kişiler arası problem çözme becerilerinin kazandırılmasında eğitimin etkisinin incelenmesi (Yayınlanmamış doktora tezi). Hacettepe Üniversitesi Sağlık Bilimleri Enstitüsü, Ankara.

Dlncer, Ç. \& Güneysu, S. (1997). Examining the effects ofproblem-solving training on the acquisition of Interpersonal problem-solving skills by 5 -year-old children in turkey. International Journal of Early Years Education, 5(1), 37-46, https://doi.org/10.1080/0966976970050104

Dinçer, Ç. \& Güneysu, S. (2001). Examining the permanence of problem solving training given for the acquisition of interpersonal problem solving skills. International Journal of Early Years Education, 19 (3), 207-219. https://doi.org/10.1080/09669760120086956

Dinçer, Ç., Anlıak, Ş., Şahin, D. \& Karaman, G. (2009). Kişilerarası bilişsel problem çözme programının okul öncesi eğitimi kurumlarında yaygınlaştırılması projesi. Uluslararası Katılımlı II. Çocuk Gelişimi ve Eğitimi Kongresi, Hacettepe Üniversitesi, Ankara.

Dilber, M. (2015). Okulöncesi çocukların ahlaki yargı düzeyleriyle kişilerarası problem çözme becerileri arasındaki ilişkinin incelenmesi (Yayınlanmamış yüksek lisans tezi). Gazi Üniversitesi Eğitim Bilimleri Enstitüsü, Ankara. 
Domitrovich, C., Cortes, M. T., \& Greenberg,R. C. (2007). Improving young children's social and emotional competence: a randomized trial of the preschool "paths" curriculum. The Journal of Primary Prevention, 28 (2), 67-91. https://doi.org/10.1007/s10935-007-0081-0

Duman, B. (2009). Neden beyin temelli öğrenme. Ankara: Pegem.

Emir, S. H. (2016). Okul öncesi çocukların evlilik çatışması algısı ile kişiler arası problem çözme becerileri arasındaki ilişkinin incelenmesi (Yayınlanmamış yüksek lisans tezi). İstanbul Üniversitesi Sosyal Bilimler Enstitüsü, İstanbul.

Eroğlu, E. (2001). Ailenin çocuklarda problem çözme yeteneğinin gelişmesi üzerindeki etkisi (Yayınlanmamış yüksek lisans tezi). Sakarya Üniversitesi Sosyal Bilimler Enstitüsü, Sakarya.

Erwin, G. P., Purves, G. D. \& Johannes, C. K. (2005). Involvement and outcomes in short-term interpersonal cognitive problem solving groups. Counselling Psychology Quarterly, 18(1), 41-46. https://doi.org/10.1080/09515070500099694

Fan, X. \& Chen, M. (2001). Parental involvement and students' academic achievement: A meta-analysis. Educational Psychology Review, 13 (1), 1-22. https://doi.org/10.1023/A:1009048817385

Gök, G. (2009). Boyama kitaplarının anaokullarında eğitim gören çocukların yaratıcılıklarına olan etkisinin incelenmesi (Yayınlanmamış yüksek lisans tezi). Gazi Üniversitesi Eğitim Bilimleri Enstitüsü, Ankara.

Hamre, B. K., Pianta, R. C., Mashburn, A J. \& Downer, J. T. (2012). Promoting young children's social competence through the preschool paths curriculum and my teaching partner professional development resources. Early Education and Development, 23(6), 809 832. https://doi.org/10.1080/10409289.2011.607360

Hune, B. J., \& Nelson, M. C. (2002). Effects of teaching a problem-solving strategy on preschool children with problem behavior. Behavioral Disorders, 27(3), 185-207. https://doi.org/10.1177/019874290202700302

Işıktekiner, F. S. (2014). Anne baba destek programının okul öncesi dönem (48-60 aylık) çocuklarının kişiler arası problem çözme becerilerine etkisi (Yayınlanmamış yüksek lisans tezi). Ankara Üniversitesi Eğitim Bilimleri Enstitüsü, Ankara.

Kaan, S. (2013). Kişilerarası sorun çözme becerileri eğitimi programının okul öncesi dönem çocukları üzerindeki etkis. (Yayınlanmamış yüksek lisans tezi). Erciyes Üniversitesi Eğitim Bilimleri Enstitüsü, Kayseri.

Kaçar, S. (2016). Okul öncesi normal gelişim gösteren 5-6 yaş grubu çocukların tercih ettikleri oyun türlerinin dil gelişimi ve problem çözme becerisi üzerine etkisinin incelenmesi (Yayınlanmamış yüksek lisans tezi). Maltepe Üniversitesi Sosyal Bilimler Enstitüsü, İstanbul.

Kağıtçıbaşı, Ç., Sunar, D., Bekman, S. \& Cemalcılar, Z. (2004). Erken müdahalenin erişkinlikte süren etkileri. Erken destek projesinin ikinci takip araştırmasının ön bulguları. İstanbul: Anne-Çocuk Eğitim Vakfı Yayınları.

Kalaycı, Ş. (2014). SPSS uygulamalı çok değişkenli istatistiksel teknikler (6th ed.), Ankara: Asil Yayın Dağıtım.

Karayol, S. (2016). Yapılandırılmış ve yapılandırılmamış oyun etkinliklerini içeren eğitim programının 5 yaş grubu çocukların işbirliği davranışlarına ve problem çözme becerilerine etkisi (Yayınlanmamış doktora tezi). Gazi Üniversitesi Eğitim Bilimleri Enstitüsü, Ankara.

Kargı, E. ( 2009 ). Bilişsel yaklaşıma dayalı kişiler arası sorun çözme becerileri kazandırma (BSÇ) programının etkililiği: Okul öncesi dönem çocukları üzerinde bir araştırma (Yayınlanmamış doktora tezi). Ankara Üniversitesi Eğitim Bilimleri Enstitüsü, Ankara.

Kaytez, N. \& Kadan, G. (2016). Okul öncesi dönem çocuklarında akademik benlik saygısı ile kişiler arası problem çözme becerilerinin incelenmesi. Eğitim ve Öğretim Araştırmaları Dergisi, 5(38). 332-342.

Keçecioğlu Ö. (2015). MEB okul öncesi eğitim programı ve montessori yaklaşımına göre eğitim alan 5 yaş çocuklarının sosyal becerilerinin incelenmesi (Yayınlanmamış yüksek lisans tezi). Marmara Üniversitesi Eğitim Bilimleri Enstitüsü, İstanbul. 
Kenç. M. F. (2004). Kişiler arası sorunların çözümünde kullanılan sistematik modeller. Milli Eğitim Dergisi, p.161. Retrived from http://dhgm.meb.gov.tr/yayimlar/dergiler/Milli Egitim Dergisi/161/kenc.htm

Kesicioğlu, O. S. (2015). Okul öncesi dönem çocukların kişilerarası problem çözme becerilerinin incelenmesi. Eğitim ve Bilim, 40(177), 327-342. http://dx.doi.org/10.15390/EB.2015.3240

Koruklu, N. \& Yılmaz, N. (2010). Çatışma çözme ve arabuluculuk eğitimi programının okulöncesi kurumlara devam eden çocukların problem çözme becerisine etkisi. Adnan Menderes Üniversitesi Eğitim Fakültesi Eğitim Bilimleri Dergisi, 1(1), 1-20.

Ladd, G. W., Kochenderfer-Ladd, B., \& Coleman, C. C. (1996). Friendship quality as a predictor of young children's early school adjustment. Child Development, 67, 1103-1118. https://doi.org/10.1111/j.1467-8624.1996.tb01785.x

MEB (2013). (36-72 aylık) Okul öncesi eğitim programı. Ankara: Millî Eğitim Bakanlığı Talim ve Terbiye Kurulu Başkanlığı.

Mercan, M. (2019). Okul öncesi eğitim kurumlarına devam eden 5-6 yaş çocuklarının öz düzenleme becerileri ile akademik benlik saygıları ve kişilerarası problem çözme becerileri arasındaki ilişkinin incelenmesi (Yayınlanmamış yüksek lisans tezi). Gazi Üniversitesi Eğitim Bilimleri Enstitüsü, Ankara.

Mermer, H. (2017). Okul öncesi dönem çocuklarının kişilerarası sorun çözme becerilerini geliştirmede "sorunlarımızı çözebiliriz oyunu"nun ve serbest oyunun etkisinin incelenmesi (Yayınlanmamış yüksek lisans tezi). Ankara Üniversitesi Eğitim Bilimleri Enstitüsü, Ankara.

Ocak, Ş. \& Arda, T. B. (2012). Sosyal yeterlilik ve alternatif düşünme stratejilerinin desteklenmesi -ADSD okul öncesi program. Kuram ve Uygulamada Eğitim Bilimleri, 12 (4), 2679-2698.

Oğuz, V. (2012). Proje yaklaşımının anasınıfına devam eden çocukların problem çözme becerilerine etkisinin incelenmesi (Yayınlanmamış doktora tezi). Ankara Üniversitesi Fen Bilimleri Enstitüsü, Ankara.

Öğülmüş, S. (2006). Kişiler arası sorun çözme becerileri ve eğitimi (3rd ed.). Ankara: Nobel Yayıncılık.

Öğülmüş, S. \& Kargı, E. (2015). The interpersonal cognitive problem solving approach for preschoolers. Turkish Journal of Education, 4(1), 19-28. https://doi.org/10.19128/turje.31501

Özcan, C. \& Öğülmüş, S. (2010). Dikkat eksikliği hiperaktivite bozukluğu olan çocuklara bilişsel yaklaşıma dayalı kişilerarası sorun çözme eğitiminin katkıları. TAF Preventive Medicine Bulletin, 9 (4), 391-398.

Özdil, G. (2008). Kişilerarası problem çözme becerileri eğitimi programının okul öncesi kurumlara devam eden çocukların kişilerarası problem çözme becerilerine etkisi (Yayınlanmamış yüksek lisans tezi). Adnan Menderes Üniversitesi Sosyal Bilimler Enstitüsü, Aydın.

Özmen, D. (2013). 5-6 Yaş grubu çocukların akran ilişkilerinin sosyal problem çözme becerisi açısından incelenmesi (Yayınlanmamış yüksek lisans tezi). Selçuk Üniversitesi Eğitim Bilimleri Enstitüsü, Konya.

Piaget, J. (1983). Piaget's theory. P. Mussen (ed). Handbook of Child Psychology (4th ed.), Vol. 1. New York: Wiley.

Shure, M. (1992a). I can problem solve (ICPS): An interpersonal cognitive problem solving program (kindegarten/primary grades). Illinois, Champain: Research Press.

Shure, M. (1992b). Preschool interpersonal problem solving (PIPS) test: Manual. Department of Psychology, Drexel University, Philadelphia.

Shure, M.B. (1997). Interpersonal cognitive problem solving: Primary prevention of early high-risk behaviors in the preschool and primary years. In G.W. Albee and T.P. Gullotta (Eds.) Primary Prevention Works (pp.167-188). Thousand Oaks, CA: Sage.

Shure, M. B. (2001). I can problem solve: Intermediate elementary grades (Vol. 3). Research Press. 
Shure M. B. \& Spivack G. (1982). Interpersonal problem solving in young children: A cognitive approach to prevention. American Journal of Community Psychology, 10(3), 341-356. http://dx.doi.org/10.1007/BF00896500

Spivak, G., \& Shure, M. B. (1985). ICPS and beyond: Centripetal and centrifugal forces. American Journal of Community Psychology, 13, 226-243. http://dx.doi.org/10.1007/BF00914931

Swets, P. W. (1998). Ergen çocuğunuzla konuşma sanatı (B.Atlamaz, Çev.), İstanbul: Varlık Özel Yayınları.

Tangül Özcan, C. (2007). Kişiler arası sorun çözme eğitiminin dikkat eksikliği hiperaktivite bozukluğu olan çocuklardaki karşı gelme belirtileri üzerine etkileri (Yayınlanmamış doktora tezi). Gülhane Askeri Tıp Akademisi Sağlık Bilimleri Enstitüsü, Ankara.

Terzi, S. (2003). Altıncı sınıf öğrencilerinin kişilerarası problem çözme beceri algıları. Türk Eğitim Bilimleri Dergisi, 1(2), 221-231.

Türköz, Y. (2007). Okul öncesi çocuklarda bağlanma örüntüsünün kişilerarası problem çözme ve açık bellek süreçlerine etkisi (Yayınlanmamış doktora tezi). Ankara Üniversitesi Sosyal Bilimler Enstitüsü, Ankara.

Uysal, H. (2016). Eşsiz yıllar müdahale programı çocuk boyutu'nun uyarlanması ve programın etkililiğinin araştırılması (Yayınlanmamış doktora tezi). Hacettepe Üniversitesi Eğitim Bilimleri Enstitüsü, Ankara.

Ünal, M. \& Aral, N. (2014). Fen eğitiminde problem çözme ölçeğinin geliştirilmesi: Geçerlik ve güvenirlik çalışmaları. Eğitim ve Bilim, 39(176), 267-278. http://dx.doi.org/10.15390/EB.2014.3585

Webster Stratton, C. \& Reid, M. J. (2003). Treating conduct problems and strengthening social and emotional competence in young children the Dina Dinosaur treatment program. Journal of $\begin{array}{llll}\text { Emotional and } \quad \text { Behavioral 130-143. } & \text { Disorders, }\end{array}$ http://dx.doi.org/10.1177/10634266030110030101

Yıldırım, A., Hacıhasanoğlu, R., Karakurt, P. \& Türkleş, S. (2011). Lise öğrencilerinin problem çözme becerileri ve etkileyen faktörler. Uluslararası Insan Bilimleri Dergisi, 8(1), 905-921.

Yılmaz, E. (2012). 60-72 aylık çocukların duyguları anlama becerilerinin sosyal problem çözme becerilerine etkisinin incelenmesi (Yayınlanmamış yüksek lisans tezi). Selçuk Üniversitesi Sosyal Bilimler Enstitüsü, Konya.

Yılmaz, G. (2019). Okul öncesi eğitim alan çocukların duygu düzenleme ve sosyal problem çözme becerilerine yaratıcı drama eğitiminin etkisi (Yayınlanmamış yüksek lisans tezi). Kırklareli Üniversitesi Sağlık Bilimleri Enstitüsü, Kırklareli.

Yoleri, S. (2014). Okul öncesi çocukların kişiler arası problem çözme becerisi ile kavram gelişimleri arasındaki ilişkinin incelenmesi. Eğitim ve Bilim, 39 (173), 82-91.

İletişim/Correspondence

Doktorant Hilal ZORLU,

hilalkaratekin@gmail.com

Prof. Dr. Selahiddin Öğülmüş,

s.ogulmus@gmail.com 